[Agr. Biol. Chem., Vol. 33, No. 5, p. 729 738, 1969]

\title{
Purification and Some Properties of a Fungal Lipase Preparation Used for Milk Flavouring
}

\author{
By Susumu Oi, Osamu Yamazaki, Akira SAwada * \\ and Yukio SATOMURA \\ Faculty of Sctence, Osaka City University \\ Received August 30, 1968
}

\begin{abstract}
Intracellular lipase of a strain of Rhizopus fungus which is effective for producing a milk flavor was purified and fractionated into two components, I and II, by DEAE Sephadex A-50 column chromatography. They both proved homogeneous by electrophoresis and ultracentrifugal analysis. The sedimentation coefficient was respectively calculated to be $5.8 \times 10^{-13}$ for lipase $I$, and to be $2.2 \times 10^{-13}$ for lipase II. From substrate specificity, it was found that lipase I was an ordinary lipase hydrolyzing olive oil and tributyrin favourably, while, II, rather, a special lipase having a high affinity towards tricaprylin. They, also, respectively had an apparent phospholipase activity on soy-lecithin and, clearing activity on chylomicron prepared from olive oil and human serum. Their mode of action, and the effect of metals and emulsifying agents on their activity are also presented.
\end{abstract}

It is known that certain lipolytic enzymes are available to improve the milk flavour which is of great significance on quality of diary products, by changing the constitution of free fatty acids in milk. ${ }^{11}$ There must be a close relation between the effectiveness of such lipase on producing a pleasant milk smell and the substrate specificity of the enzyme. Recently, it has been made clear that the substrate specificities of microbial lipases are different from each other little by little with the origins. ${ }^{2 \sim 7)}$ Some lipases from microbial and animal origins were found to have an

* Osaka Saikin Kenkyüsho Ltd., Taisha-chyō, 955, Nishinomiya City.

1) United States Patent No. 2794743.

2) S. Tatsuoka, A. Miyake, S. Wada and C. Matsumura, J. Biochem., 46, 575 (1959).

3) J. Fukumoto, M. Iwai and Y. Tsujisaka, $J$. Gen. Appl. Microbiol., 9, 353 (1963).

4) J. Fukumoto, M. Iwai and Y. Tsujisaka, ibid., 10, 257 (1964).

5) Y. Satomura, S. Oi, A. Sawada and J. Fukumoto, Agr. Biol. Chem., 24, 329 (1960).

6) S. Oi, A. Sawada and Y. Satomura, ibid., 31, 1357 (1967).

7) J. A. Alford, D. A. Pierce and F. G. Suggo, $J$. Lipid Res., 5, 390 (1964). activity on substrate other than glyceride such as Tween, phospholipid and lipoprotein. ${ }^{8,91}$ It is of interest to investigate and compare the substrate specificities and properties of these lipase, with referring to the effect on milk flavouring. In this paper, the purification and characterization of a commercial Rhizopus lipase preparation which is at preseht used as flavouring enzyme on milk products are dealt.

\section{METHOD AND MATERIALS}

Crude enzyme preparation. A commercial Rhizopus lipase preparation** which is the extract from the mycelium of submerged culture of a Rhizopus fungus (unidentified strain) was extracted twice with a dilute diammoniumhydrogen-phosphate solution. The extract was salted out with 0.9 saturation of ammonium sulfate. The precipitate was collected by centrifuga-

8) Y. Satomura, M. Ono, S. Oi and J. Fukumoto, Agr. Biol. Chem., 25, 15 (1961).

9) K. Arima, T. Narasaki, Y. Nakamura and G. Tamura, ibid., 31, 924 (1967).

** Products of Osaka Saikin Kenkyüsho Ltd. 
tion at $4000 \mathrm{rpm}$ for $20 \mathrm{~min}$, dissolved in a small volume of water, and dialyzed against distilled water. The dialyzed solution was used as crude enzyme preparation.

Measurement of activity. Reaction mixture containing $4 \mathrm{ml}$ of olive oil emulsion $(0.25 \mathrm{~g}$ olive oil $/ \mathrm{l} \mathrm{ml}$ of $1.5 \%$ polyvinylalcohol), $2 \mathrm{ml}$ of $0.1 \mathrm{M}$ Mcllvaine buffer $(\mathrm{pH} 6.0), 1 \mathrm{ml}$ of enzyme solution, $1 \mathrm{ml}$ of $0.2 \mathrm{M}$ calcium chloride solution and $2 \mathrm{ml}$ of distilled water, was usually incubated at $37^{\circ} \mathrm{C}$ for $120 \mathrm{~min}$ in a test tube $(1.5 \times 12.5 \mathrm{~cm})$ plugged with a rubber stopper in stationary condition, unless otherwise stated. Then, the mixture was poured into a flask with $30 \mathrm{ml}$ of $95 \%$ ethylalcohol, and after warming at $55^{\circ} \mathrm{C}$ for $20 \mathrm{~min}$, free fatty acid liberated was titrated against $0.05 \mathrm{~N} \mathrm{NaOH}$ using a potentiometer. One unit of the lipase activity was defined as that amount of enzyme which produces $1 \mu$ mole of free fatty acid under the condition. Specific activity was expressed by units per $\mathrm{mg}$ protein, and protein quantity was determined spectrophotometrically at $280 \mathrm{~m} \mu$ applying the factor $E_{j \mathrm{~cm}}^{1 \%}=14.5$ which was estimated from the dry weight of the purified preparation.

Gas-liquid chromatography. The constitution of free fatty acids in the hydrolysates by enzyme was analyzed by a gas-liquid chromatography using Yanagimoto model $550 \mathrm{~T}$ gas chromatograph. The hydrolysates were developed on silica gel thin-layer, and the location of free fatty acids was detected by spraying 75\% sulfuric acid and heating. The bands corresponding to the free fatty acids on thin-layer chromatogram were scraped up by a spoon, and extracted with petroleum ether. To convert the fatty acids in the extract to methyl esters, the extract was evaporated to a small volume, mixed with $4 \mathrm{ml}$ of $0.7 \mathrm{~N}$ anhydrous methanolic hydrochloric acid, and refluxed for $2 \mathrm{hr}$ at $80^{\circ} \sim 100^{\circ} \mathrm{C}$. After cooling and adding $1 \mathrm{ml}$ of water, the mixture was extracted three times with $3 \mathrm{ml}$ of petroleum ether. The extracts were combined and evaporated to about $1 \mathrm{ml}$ under a stream of nitrogen. A portion of the concentrate (weighing about $5 \sim 25 \mu \mathrm{g}$ ) was sampled, and developed on silicone $\mathrm{SE}-30$ with hydrogen gas at $210^{\circ} \mathrm{C}$.

Clearing activity. Clearing activity on chylomicron was measured by using a spectrophotometer, turbidimetrically. Chylomicron was prepared as the following; $1 \mathrm{ml}$ of olive oil emulsion ( $1 \mathrm{~g}$ olive oil/ $3.0 \mathrm{ml}$ of $2 \%$ polyvinylalcohol) was incubated with
$9 \mathrm{ml}$ of human serum for $1 \mathrm{hr}$ at $37^{\circ} \mathrm{C}$.

Hemolytic effect. Hemolytic effect of enzyme was tested on human erythrocytes according to the Slotta's method.101

Ultracentrifugal analyses. These were carried out at Faculty of Medicine of this university using a Hitachi Analytical Ultracentrifuge UCA -1 . The sedimentation coefficient was calculated as described by Schachman, ${ }^{111}$ and was corrected to $20^{\circ} \mathrm{C}$ in water, according to the method described by Svedberg. ${ }^{12}$;

Electrophoresis. Electrophoretic experiments were carried out using a Hitachi Tiselius Electrophoretic Apparatus HT-B.

\section{EXPERIMENTAL AND RESULTS}

\section{Purification of lipase}

The purification procedure is summarized in Table $\mathrm{I}$. The crude enzyme solution diluted with $0.025 \mathrm{~m}$ Tris-HCl buffer ( $\mathrm{pH} 9.1$ ) was passed through DEAE cellulose column $(2.2 \times 60 \mathrm{~cm})$ which had been equilibrated with $0.025 \mathrm{~m}$ Tris-HCl buffer ( $\mathrm{pH} 9.1$ ), whereby the lipase was adsorbed on the column. The column was eluted with a linear gradient $\mathrm{pH}$ change of Tris-HCl buffer from 9.1 to 7.2 by using the mixing chamber containing $2000 \mathrm{ml}$ of $0.025 \mathrm{M}$ Tris-HCl buffer ( $\mathrm{pH} \mathrm{9.1)} \mathrm{and} \mathrm{the}$ reservoir containing $2000 \mathrm{ml}$ of $0.025 \mathrm{~m}$ Tris$\mathrm{HCl}$ buffer ( $\mathrm{pH} 7.2$ ). The main lipase which has a high specific activity was eluted at $\mathrm{pH}$ 8.8. Then, the lipase fraction obtained was brought to 0.9 saturation with ammonium sulfate, and allowed to stand over night at $4^{\circ} \mathrm{C}$. The resulting precipitates were collected by centrifugation, dissolved in a small volume of distilled water, and dialyzed against distilled water. After adjusting $\mathrm{pH}$ to 7.0 with $0.1 \mathrm{~m}$ phosphate buffer the dialyzed solution was applied on the Sephadex G-200 column

10) K.H. Slotta and G. Szyzka, Ber., 71, 258 (1938).

11) H. K. Schachman, "Methods in Enzymology,' Academic Press INC., New York, (1957) p. 32.

12) T. Svedberg and D. K. Pederson, "The Ultracentrifuge," Claredon Press, Oxford (1940) p. 445. 
TABle I. PURIFICATION OF Rhizopus LIPASE I AND II

Procedure

Crude enzyme solution

$\downarrow$

Adsorbed on DEAE cellulose column equilibrated with

$0.025 \mathrm{M}$ Tris- $\mathrm{HCl}$ buffer at $\mathrm{pH} 9.1$

$\downarrow$

Eluted by changing $\mathrm{pH}$ of Tris-HCl buffer, linearly from 9.1 to 7.2

Eluate

$\downarrow$

Ppt.

$\downarrow$

Chromatography on Sephadex G-200 column equilibrated with

0.1 M phosphate buffer at $\mathrm{pH} 7.0$

Eluate

Eluate

Ppt. with 0.9 satur. of $\left(\mathrm{NH}_{4}\right)_{2} \mathrm{SO}_{4}$ and dialyzed against water

$\downarrow$

Adsorbed on DEAE Sephadex A-50 column equilibrated with

$0.02 \mathrm{M}$ veronal buffer at $\mathrm{pH} 8.0$

1

Eluted by changing mol. concn. of $\mathrm{NaCl}$

$\stackrel{\downarrow}{\text { Eluate }}$

Lipase II
Lipase I
Ppt. with 0.9 satur. of $\left(\mathrm{NH}_{4}\right)_{2} \mathrm{SO}_{4}$ and dialyzed against water
Adsorbed on $\mathrm{CM}-\mathrm{Sephadex} \mathrm{C}-50$ column equilibrated with
$0.02 \mathrm{M}$ phosphate buffer at $\mathrm{pH} 6.0$
$\downarrow$
Eluted by changing pH of phosphate buffer, linearly from 6.0 to 7.5
$\downarrow$

$\begin{array}{ccc}\text { Vol. ml } & \begin{array}{c}\text { Total } \\ \text { activity } \\ \text { units }\end{array} & \begin{array}{c}\text { Specific } \\ \text { activity } \\ \text { units/mg } \\ \text { protein }\end{array} \\ 3600 & 900,000 & 50\end{array}$

1000

150,000

175

200

140,000

200

120

60,000

500

40

55,000

575

$\begin{array}{rrr}120 & 15,400 & 425 \\ 120 & 17,000 & 500 \\ 30 & 15,000 & 600\end{array}$

36

13,000

625
$(3.0 \times 120 \mathrm{~cm})$ which had been equilibrated with $0.1 \mathrm{~m}$ phosphate buffer ( $\mathrm{pH} 7.0$ ). The column was eluted with the same buffer and the eluate at tube No. 99 to 110 was collected, as presented in Fig. 1. Then, the lipase fraction collected was brought to 0.9 saturation with ammonium sulfate, and allowed to stand over night at $4^{\circ} \mathrm{C}$. The resulting precipitates were collected by centrifugation, dissolved in a small volume of distilled water, and dialyzed against distilled water. After adjusting $\mathrm{pH}$ at 8.0 with $0.02 \mathrm{M}$ veronal buffer the dialyzed solution was adsorbed on the DEAE Sephadex A-50 column
$(2.2 \times 56 \mathrm{~cm})$ which had been equilibrated with 0.02 M veronal buffer ( $\mathrm{pH} 8.0$ ), whereby the enzyme was again adsorbed on the column. The column was eluted with a linear gradient change of the concentration of $\mathrm{NaCl}$ from 0 to $1.5 \mathrm{~m}$ by using the mixing chamber containing $500 \mathrm{ml}$ of $0.02 \mathrm{M}$ veronal buffer ( $\mathrm{pH} \mathrm{8.0)}$ and the reservoir containing $500 \mathrm{ml}$ of the same buffer to which $\mathrm{NaCl}$ was added in $1.5 \mathrm{M}$ concentration, as presented in Fig. 2 . The lipase I (peak 1) and II (peak II) are respectively eluted at tube No. 10 and No. 75 , where the concentration of $\mathrm{NaCl}$ was respectively 0.17 and $1.0 \mathrm{~m}$. Then, after adjust- 
ing $\mathrm{pH}$ to 6.0 with $0.02 \mathrm{~m}$ acetate buffer the lipase I fraction was again adsorbed on CM Sephadex C-50 column which had been equilibrated with $0.02 \mathrm{M}$ acetate buffer $(\mathrm{pH} 6.0$ ), and eluted at $\mathrm{pH} 6.5$ with a linear gradient $\mathrm{pH}$ change of acetate buffer 6.0 to 7.5 , as seen in Fig. 3. In this way, the activity of lipase I was attained to 12.5 fold per $\mathrm{mg}$ protein, and that of lipase II attained to 8.5 fold.

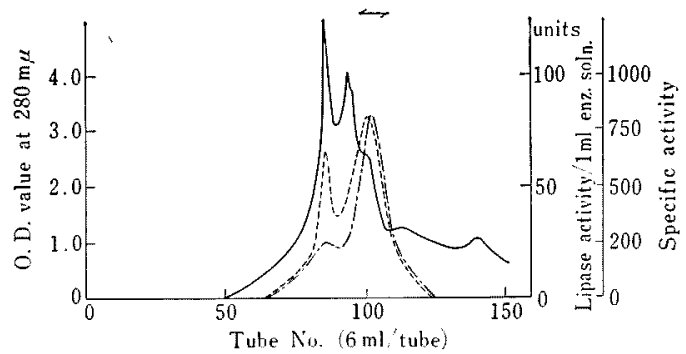

FIG. 1. Chromatography on Sephadex

$\mathrm{G}-200$ Column

Column size: $3.0 \times 120 \mathrm{~cm}$.

Flow rate : About $6 \mathrm{ml} / \mathrm{hr}$.

— : OD value.

:-..- Lipase activity.

:-_ Specific activity.

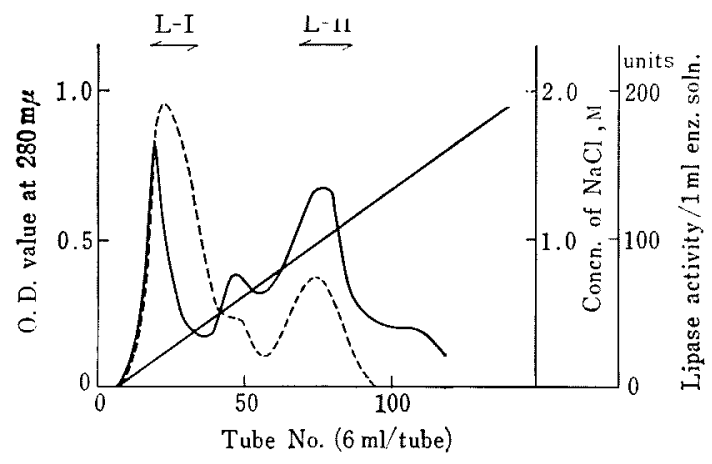

FIG. 2. Chromatography on DEAE-Sephadex A-50.

$$
\begin{aligned}
\text { Column size: } & 2.4 \times 56 \mathrm{~cm} . \\
- & \text { OD value. } \\
& : \text { Lipase activity. }
\end{aligned}
$$

\section{Homogeneity of purified lipase}

a) Gel-filtration. As presented in Fig. 4, the gel-filtration of lipase I and II on Sephadex

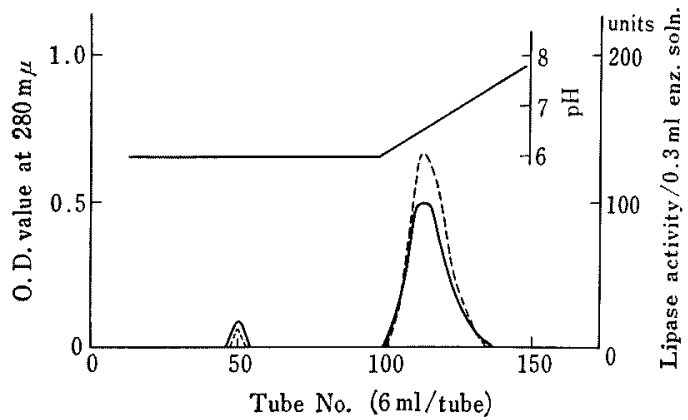

FIG. 3. Chromatography of Lipase I on CMSephadex C-50.

Column size: $2.4 \times 56 \mathrm{~cm}$.

$$
\begin{aligned}
& \text { —... } \quad \text { OD value. } \\
& \ldots \quad \text { Lipase activity. }
\end{aligned}
$$
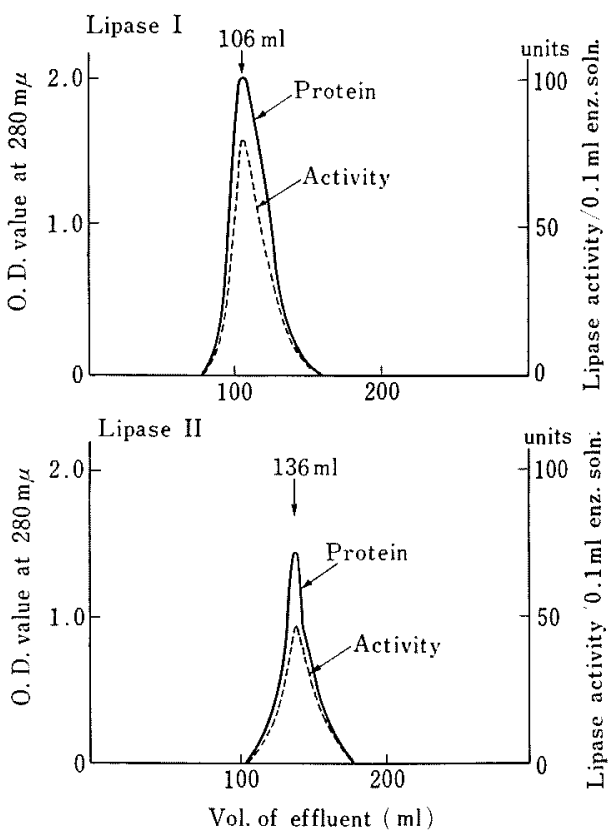

FIG. 4. Gel-Filtration of Lipase I and II on a Sephadex G-100 Column.

Column size: $2.4 \times 58 \mathrm{~cm}$.

Buffer : Phosphate buffer at $\mathrm{pH}$ 7.0. 


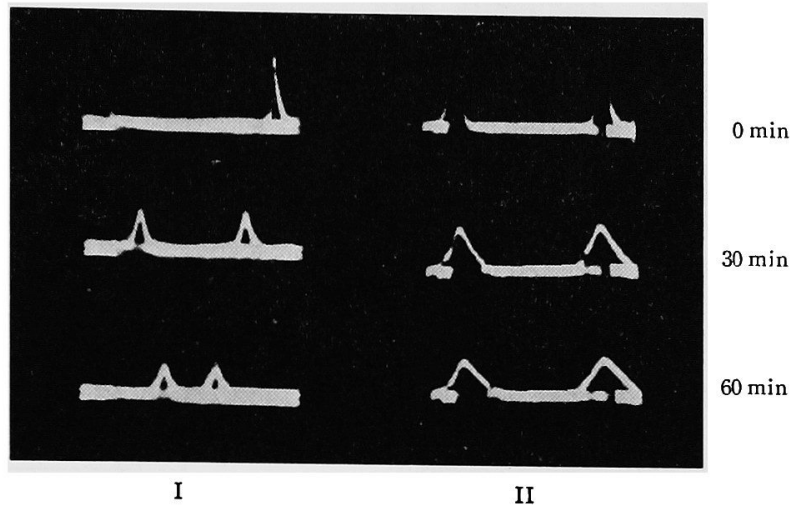

FIG. 5. Electrophoretic Patterns of Lipase I and II.

I : $0.6^{\circ} \circ$ of lipase I in $0.02 \mathrm{M}$ veronal buffer ( $\mathrm{pH} 9.20$ ).

II: $1.0 \%$ of lipase II in $0.02 \mathrm{M}$ phosphate buffer ( $\mathrm{pH} 7.5$ ).

The electrophoresis was carried out at 40 volts, 6 mamp., and $18^{\circ} \mathrm{C}$, adjusting the ionic strength to 0.2 with $\mathrm{NaCl}$.

G-100 column which was equilibrated with 0.1 м phosphate buffer ( $\mathrm{pH} 7.0$ ) showed a symmetric elution pattern, respectively, and proved their homogeneity.

b) Electrophoresis and ultracentrifugal analysis. As seen in Fig. 5, these lipases were also homogeneous electrophoretically. Ultracentrifugal analysis was operated at $20.2^{\circ} \mathrm{C}$ in a standard $12 \mathrm{~mm}, 4^{\circ}$ sector cell. The sedimentation coefficient $s_{20, w}$ was calculated from the sedimentation velocity runs shown in Fig. 6 , and a value of $5.8 \times 10^{-13}$ and $2.2 \times 10^{-13}$ was obtained respectively for lipase I and II. Also, the single peak shown in the sedimentation pattern again revealed the homogeneity of these enzymes.

\section{Characterization of lipase $I$ and $I I$}

i. Enzymatic properties

a) Optimum $p H$ and stability. As presented in Fig. 7, although optimum $\mathrm{pH}$ of the crude enzyme was 6.0, that of purified lipase I and II was rather shifted to near 3.5, where a high activity on a wide $\mathrm{pH}$ range 3.5 to 7.0 appeared, and $\mathrm{pH}$-activity curves of these two enzymes almost completely coincided. While, when $0.1 \mathrm{~m}$ of $\mathrm{NaCl}$ and $10 \mathrm{mg}$ of bile salt were added to the reaction mixture at that time, the optimum $\mathrm{pH}$ of lipase I returned to 6.5. Also, when reaction mixture was emulsified with $10 \mathrm{mg}$ of pectin, optimum $\mathrm{pH}$ of lipase I was near 6.0. As presented in Fig. 8, pH stability of these lipase were stable at $30^{\circ} \mathrm{C}$ between $\mathrm{pH} 4.0$ and 7.0 for $20 \mathrm{hr}$. As presented in Fig. 9, these enzyme were thermostable at $\mathrm{pH} 6.0$ and did not lose activity by heating the enzyme at $47^{\circ} \mathrm{C}$ for $15 \mathrm{~min}$.

\section{ii. Substrate specificity}

As shown in Table II, lipase I hydrolyzed olive oil most efficiently, and tributyrin was the second most favorable substrate. On the other hand, lipase II hydrolyzed tricaprylin much more efficiently than olive oil. The relative rate of hydrolysis by lipase I was the following, i.e. [Olive oil $>$ Tributyrin $>$ Trilaurin> Tricaprylin $>$ Triacetin] and that of lipase II, i.e. [Tricaprylin $>$ Trilaurin $>$ Olive oil $>$ Tributyrin]. Besides, these lipase both had a high activity on soy-lecithin, a tolerable activity on phosphatidylcholine, and a little activity on phosphatidylinositol. Also, lipase II could hydrolyze Tween 20 and methylbutyrate under stationary condition, and Span 20 under shak- 

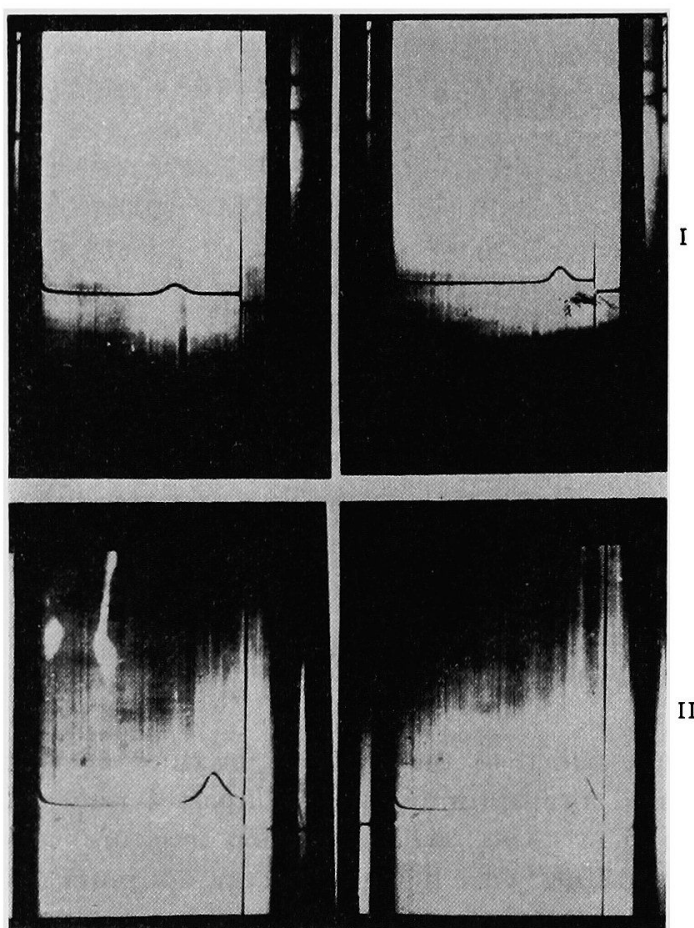

$60 \mathrm{~min}$

$30 \mathrm{~min}$

FIG. 6. Sedimentation Patterns of Lipase I and II.

I: $0.4 \%$ of lipase $\mathbf{I}$ in $0.02 \mathbf{M}$ veronal buffer $(\mathrm{pH} 8.75)$.

II: $0.6 \%$ of lipase II in the same buffer as I.

The ionic strength was adjusted to 0.2 with $\mathrm{NaCl}$.

The photographs were taken at $30 \mathrm{~min}$ and 60 min after reaching full speed.

ing condition. While lipase I only hydrolyzed Tween 20 under shaking condition.

\section{iii. Mode of action}

The hydrolysis rate of olive oil by lipase I (530 unit) reached to about $30 \%$ after $72 \mathrm{hr}$, but that by lipase II (450 unit) reached to $18 \%$ as presented in Fig. 10-a. The ether extract of the hydrolysates by lipase II was concentrated and developed on thin-layer chromatogram. As seen in Fig. 10-b, spots of oleic acid, diglyceride, monoglyceride and triglyceride were detected. The hydrolysis of olive oil by lipase II was thus proved to proceed via di- and mono- glyceride.

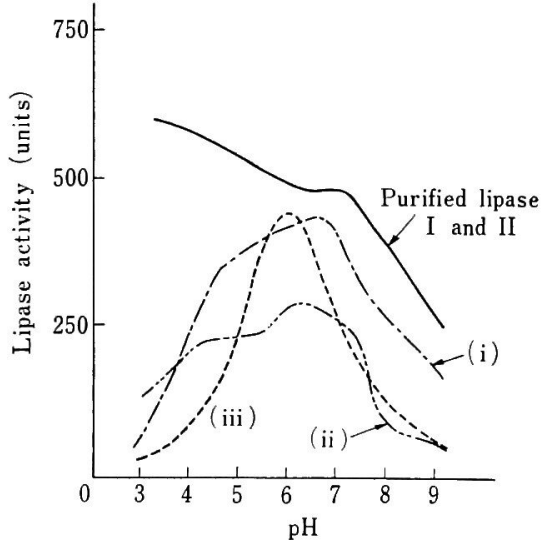

FIG. 7. pH-Activity Curve of Lipase I and II.

(i) $0.1 \mathrm{M}$ of $\mathrm{NaCl}$ and $10 \mathrm{mg}$ of bile salt was added to reaction mixture. (Purified lipase I)

(ii) Reaction mixture was emulsified with 10 mg of pectin. (Purified lipase I)

(iii) Crude enzyme.

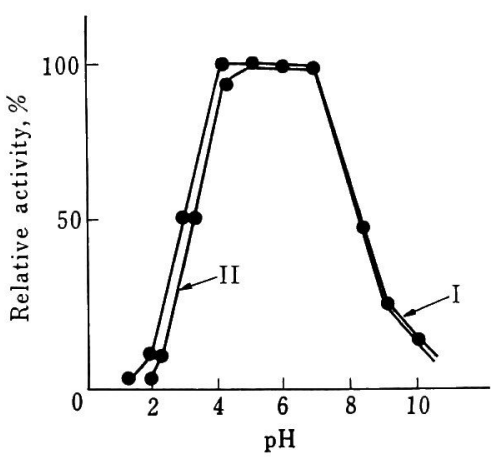

FIG. 8. pH Stability of Lipase I and II.

Incubated at $30^{\circ} \mathrm{G}$ for $22 \mathrm{hr}$.

pH 3.0 6.0: McIlvaine buffer.

pH 6.0 7.5: Phosphate buffer.

pH 7.5 9.0: $\quad \mathrm{NH}_{3}-\mathrm{NH}_{4} \mathrm{Cl}$ buffer.

The hydrolysis rate of soy-lecithin by lipase I and II reached respectively to only 10\% after $24 \mathrm{hr}$, as shown in Fig. 10-a. The chloroform extract of the hydrolysate by lipase II was concentrated and subjected to thinlayer chromatography. Lysolecithin was finely detected, as shown in Fig. 10-c. The lysolecithin was extracted with chloroform, 


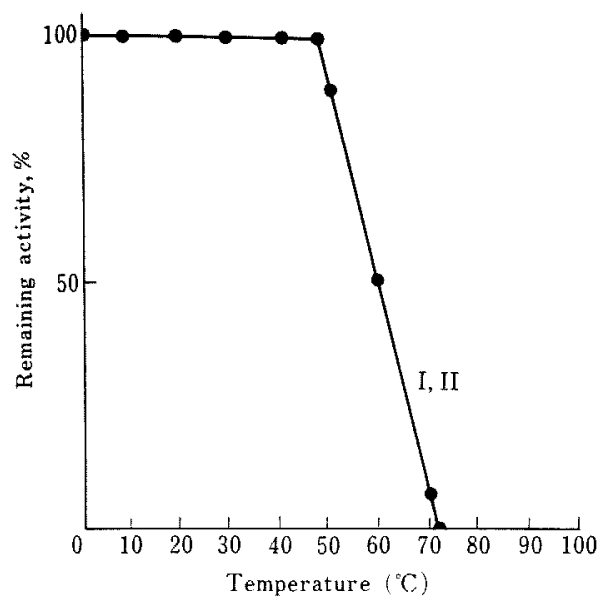

FIG. 9. Thermo-Stability of Lipase I and II. Incubated at $\mathrm{pH} 6.0$ for $15 \mathrm{~min}$. and saponified. The fatty acids liberated from lysolecithin was analyzed by gas-chromatography, as described above. As presented in Fig. 11-b, plamitic and oleic methyl ester were mainly detected in the ratio of $1: 2$. It indicated that the lysolecithin may be $\alpha$-form, because lecithin usually contains the fatty acids in the ratio of $1.5: 2$, and palmitic acid is mainly located at $\alpha$-position.

After $23 \%$ hydrolysis of lard by lipase II, the free fatty acids liberated was also analyzed by gas-chromatography as described above. (The lard used was purified by the silica gel column chromatography).

As seen in Fig. 11-a, palmitic and oleic methyl ester were detected in the ratio of $1: 2.7$. It indicated that lipase II mainly hy-

$\nabla \mathrm{TG} \quad \because$

$$
\text { FA }
$$
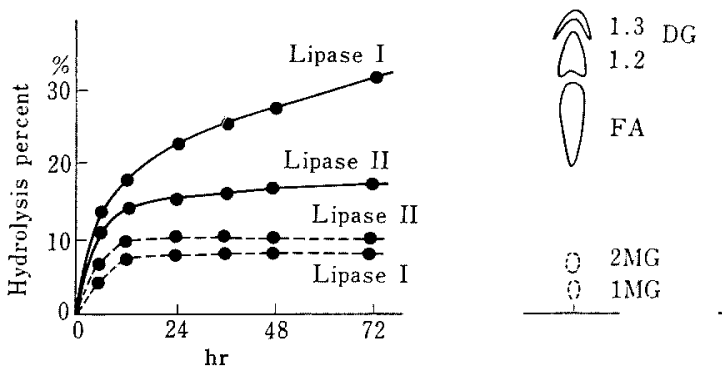

Lecithin

ij

Lysolecithin

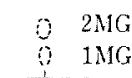

Solvent system:

Chloroform:

Methanol: $\mathrm{H}_{2} \mathrm{O}=$ 60:25:4.

96:4

Detection with conc.

Detection with

for $15 \mathrm{~min}$. reagent.

FIG. 10-a. Hydrolysis Curves of Olive oil and Soy-lecithin by Lipase I and II.

- Olive oil.

-.- Soy-lecithin.
FIG. 10-b. TLC of $\mathrm{Hy}-$ drolysate of Olive oil by Lipase II on Silica Gel GF+Boric acid $2 \%$.

TG: Triglyceride.

DG: Diglyceride.

MG: Monoglyceride.

FA. Free fatty acid.
FIG. 10-c. TLC of Hydrolysate of Soylecithin by Lipase II on Silica Gel G. 
drolyzed the ester bond of $\alpha$-position in lard, because lard contains the fatty acids in the ratio of $1: 2$, and oleic acid is mainly located at $\alpha$-position.

\section{iv. Hemolytic effect}

As shown in Table III, lipase I and II had a hemolytic effect on human erythrocytes. It may be due to the phospholipase activity.

\section{v. Clearing activity}

As shown in Fig. 12, lipase I and II had a clearing activity on chylomicron prepared as the above. However, the activity was rather lower than that of pancreatic lipase, but higher than that of crude enzyme.

vi. Effect of metals and emulsifiers

As shown in Table IV, the activity of lipase

a. Free fatty acids in lard hydrolysate.

b. Fatty acid components of lysolecithin.
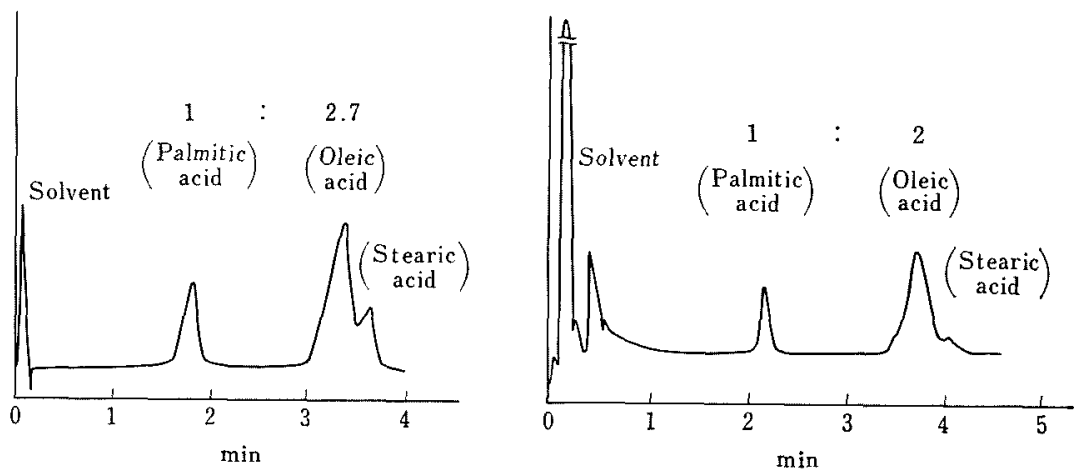

FIG. 11. Gas Chromatograms of Methyl Esters of Fatty Acids in Lard Hydrolysate and Lysolecithin.

Stationary phase: SE $3010 \%$ on Chromosorb W.

Column length : $210 \mathrm{~cm}$.

Temp. : $210^{\circ} \mathrm{C}$.

Carrier gas $\mathrm{H}_{2}$.

Flow rate : $17 \mathrm{ml} / \mathrm{min}$.

TABle II. Substrate SPecificity of LIPASE I AND II

Substrate

Olive oil

Trilaurin

Tricaprylin

Tributyrin (added $\beta$-globulin and $\mathrm{CaCl}_{2} \mathrm{M} / 50$ )

Triacetin

Tween 20

Span 20

Methyl-n-butyrate

Soy-lecithin (added albumin and $\mathrm{CaCl}_{2} \mathrm{M} / 50$ )

Phosphatidylcholine (from egg)

Phosphatidylinositol (from soy-lecithin)
Activity of

Lipase-I,

\begin{tabular}{|c|c|c|c|}
\hline Stationary & Shaking & Stationary & Shakin \\
\hline 90 & 60 & 55 & 35 \\
\hline- & 33 & - & 79 \\
\hline- & 24 & - & 179 \\
\hline 60 & 42 & 20 & 35 \\
\hline 0 & 12 & 10 & 8 \\
\hline 0 & 13 & 20 & 0 \\
\hline 0 & 0 & 0 & 20 \\
\hline 0 & 0 & 31 & 0 \\
\hline 115 & 115 & 140 & 65 \\
\hline- & 40 & - & 30 \\
\hline - & 10 & - & 15 \\
\hline
\end{tabular}

(Shaking condition: 180 times oscillation/min in $3 \mathrm{~cm}$ amplitude). 
I and II was increased by bimetalic ions such as $\mathrm{Ca}^{2+}, \mathrm{Fe}^{3+}$ and $\mathrm{Mg}^{2+}$, and also by $\mathrm{Na}^{+}$ion, but inhibited by $\mathrm{Co}^{2+}, \mathrm{Zn}^{2+}$ and $\mathrm{Fe}^{2+}$ ion.

TABLE III. Hemolytic EFfect of PuRified LIPASE

Hemolytic effect time in min

$$
\begin{aligned}
& \text { Enzyme added }
\end{aligned}
$$

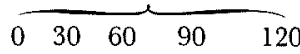

$$
\begin{aligned}
& \text { Lipase I (100 units) } \\
& \text { Heated at } 100^{\circ} \mathrm{C} \\
& \text { for } 30 \mathrm{~min} \\
& \text { Lipase II (200 units) } \\
& \text { Heated at } 100^{\circ} \mathrm{C} \\
& \text { for } 30 \mathrm{~min} \\
& - \pm++++t \\
& \begin{array}{lll}
- & - \\
- & + & +
\end{array}+++ \\
& \text { - - - - - }
\end{aligned}
$$

TABLE IV. EFFect of MEtals on ACtivity OF LIPASE I AND II

Relative activity on olive oil

$$
\text { Addition Concn. (M) }
$$

$\begin{array}{cc}\text { Lipase I } & \text { Lipase II } \\ 100 & 100 \\ 210 & 236 \\ 210 & 237 \\ 130 & 146 \\ 130 & 146 \\ 50 & 64 \\ 50 & 46 \\ 36 & 36\end{array}$

None

$\mathrm{CaCl}_{2}$

$$
2 \times 10^{-2}
$$$$
\text { "r }
$$

$\mathrm{Fe}_{2}\left(\mathrm{SO}_{4}\right)_{3}$

$\mathrm{NaCl}$

$\mathrm{MgCl}_{2}$

$\mathrm{ZnCl}_{2}$

$\mathrm{CoCl}_{2}$

$\mathrm{FeSO}_{4}$

"
"
"
"

As shown in Table $\mathrm{V}$, although the activity of crude enzyme was increased by several emulsifying agents such as polyvinylalcohol, globulin, heparin, bile salt, chondroitin, agaragar and pectin, that of purified lipase I and II was only promoted by polyvinylalcohol and globulin.

TABLE V. EFFECT OF EMULSIFIERS ON LIPASE ACTIVITY

Emulsifier added

None

$\beta$-Globulin Fract. III $\alpha$-Globulin Fract. IV

Heparin-Na

Chondroitin sulfate

Agar-agar

Pectin

Polyvinyl alcohol

Linoleic acid

Lecithin

Cholesterin

Bile salt
Conc.

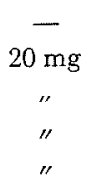

$10 \mathrm{mg}$

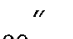

$20 \mathrm{mg}$

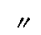

"

r

r

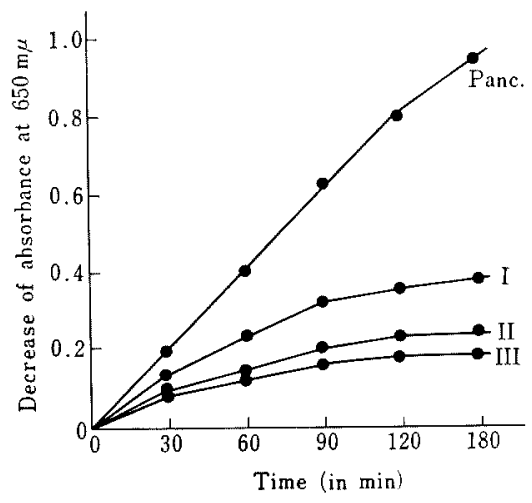

FIG. 12. Clearing Activity of Lipase I, II and Pancreatic Lipase on Serum-Olive Oil Chylomicron.

Enzymes; Panc.: A crude pancreatic lipase preparation $(2 \mathrm{mg} / \mathrm{ml})$, I: Lipase I, II: Lipase II, III: Crude Rhizopus lipase.

Reaction mixture; $1 \mathrm{ml}$ of enzyme solution, 2 $\mathrm{ml}$ of $0.3 \mathrm{M} \mathrm{NH} \mathrm{NH}_{4} \mathrm{OH}-\mathrm{NH}_{4} \mathrm{Cl}$ buffer ( $\mathrm{pH} 8.3$ ), $2 \mathrm{ml}$ of $0.2 \%$ olive oil chylomicron and $1 \mathrm{ml}$ of water.

Relative activity on olive oil

$\begin{array}{ccc}\text { Lipase I } & \text { Lipase II } & \begin{array}{c}\text { (Crude enzyme) } \\ 100\end{array} \\ 100 & (100) \\ 150 & 150 & (350) \\ 120 & 125 & (224) \\ 100 & 120 & (350) \\ 100 & 100 & (200) \\ 110 & 110 & (194) \\ 110 & 110 & (171 \text { at pH } 4.0) \\ 220 & 230 & (350) \\ 100 & 100 & (140) \\ 100 & 100 & (150) \\ 100 & 100 & (250) \\ 110 & 110 & \end{array}$




\section{DISGUSSION}

From the substrate specificity of lipase I and II shown above, it is suggested that lipase II has an important role on milk flavoring. Among the free fatty acids contained in milk, the fatty acids having a chain length of $\mathrm{C}_{6} \sim$ $\mathrm{C}_{14}$ are said to give a pleasant milk smell." It is of interest that lipase II specifically liberate the caprylic acid, as described above. Enzymatic properties of lipase I and II are very similar each other though, molecular weight of lipase II is shown to be smaller than that of lipase I from the above experiments. The difference of the substrate specificity between lipase I and II may be in part attributed to the difference in the physicochemical properties of the enzyme proteins. Recently, it has been found that two types of Penicillium lipase are convertible under an appropriate condition. ${ }^{6}$ It is possible that Rhizopus lipase I is converted to lipase II, intracellularly.

According to Haas et al. ${ }^{13 !}$ a highly purified pancreatic lipase can hydrolyze lecithin into lysolecithin, releasing mainly a saturated fatty acid. The Rhizopus lipase I and II also hydrolyze lecithin in the same manner, and have a hemolytic effect too, as shown in the above experiments. With the lipoprotein lipase activity, clearing effect of the Rhizopus lipases appears to be rather low when compared with other microbial enzymes which has been reported as lipoprotein lipase. ${ }^{9}$ It is of interest that optimum $\mathrm{pH}$ and the effect of emulsifiers on activity of Rhizopus lipase were different with the degree of purification of enzyme. It is conceivable that although there are various types of lipase in nature, the type of Rhizopus lipase II is novel.

13) G. H. De Haas, L. Sarda and J. Roger, Biochem. Biophys. Acta, 106, 638 (1965). 